\title{
Influence of Mechanization on Soybean-Safflower Cropping System in terms of Growth, Yield and Economics
}

\author{
P.O. Bhutada*, S.B. Ghuge and G.M. Kote
}

All India co-ordinated Research Project on Safflower, V.N.M.K.V., Parbhani (M.S.), India

*Corresponding author

\section{A B S T R A C T}

Keywords

Growth \& yield attributes,

Mechanization, Soybean-Safflower cropping system

\section{Article Info}

Accepted:

15 July 2020

Available Online:

10 August 2020
A field experiment was conducted at All India co-ordinated Research Project on Safflower, V.N.M.K.V., Parbhani on a clayey soil during Rabi season of 2018 to find out the effect of with two factors viz., Selective mechanization plot (SMP) and Farmer practice (FP) with two treatments. Each experimental unit was non replicated. The fertilizer dose of 40:40:20 NPK kg ha ${ }^{-1}$ was applied at the time of sowing. The field experiment consist of treatment combinations for comprising practices on mechanization and non-mechanization (Farmer practice) i.e. sowing, spraying and harvesting on soybean-safflower cropping sequence. Experiment was laid out in two different plots each having $1000 \mathrm{~m}^{2}$ area without replication one is under mechanization another one non-mechanization i.e. farmer practices for sowing, intercultural operations, spraying and harvesting, so that it tested in T-test plot design. The results of the experiments revealed that, application of mechanization practices in soybean-safflower cropping systems recorded significantly higher growth and yield of safflower than farmer practices. The seed yield was observed $24 \%$ increase under mechanized condition than to farmer's practice.

\section{Introduction}

Oilseed crops are the second most important determinant of agricultural economy, next only to cereals within the segment of field crops. Among oilseed Safflower (Carthamus tinctorius L.) is an important oilseed crop with $35-40 \%$ oil. It has been used as a source of edible oil and dying since ancient time (Kolsaric1 et al., 2005). Mechanization in safflower crop will help to timely field operation and easy for harvesting and save huge cost of cultivation and sort the labour problem of farmer. Also help to meet the growing demand for food grains and other food and non-food commodities, expansion of farm mechanization is becoming inevitable (Srivastava, 2006). Mechanization is an important input to agriculture for performing timely farm operations, reducing the cost of operation, maximizing the utilization efficiency of costly inputs (seeds, fertilizer, plant protection chemicals, water and agricultural machinery, improving the 
productivity of land and labour. There is need tore-look' and 'reengineer' the process of farm mechanization so that it effectively includes small and marginal farmers (Aggrawal, 1983). This study is therefore carried out to determine suitable farm mechanization practice.

\section{Materials and Methods}

A field experiment was conducted during the period of 2018-19 at All India co-ordinated Research Project on Safflower, V.N.M.K.V., Parbhani. The soil was clayey in texture, low in available nitrogen (231 $\mathrm{kg} \mathrm{ha}^{-1}$ ), low in available phosphorus $\left(12.64 \mathrm{~kg} \mathrm{ha}^{-1}\right)$, rich in available potash (474 $\left.\mathrm{kg} \mathrm{ha}^{-1}\right)$, sulphur (15.25 $\mathrm{kg} \mathrm{ha}^{-1}$ ) and slightly alkaline in reaction. The soil was moderately alkaline in reaction (8.13 $\mathrm{pH})$. In general, weather conditions were favorable for plant growth and no severe pest and diseases noticed during experimentation. The study involved twelve treatment combinations two factors viz., Selective mechanization plot (SMP) and Farmer practice (FP) with two treatments. Each experimental unit was non replicated having Plot size $1000 \mathrm{~m}^{2}$ each of mechanical and normal plots. Sowing was completed as per treatments. The fertilizer dose of 40:40:20 NPK $\mathrm{kg} \mathrm{ha}^{-1}$ was applied at the time of sowing. The package of recommended practices was adopted to maintain the crop.

\section{Results and Discussion}

\section{Effects on growth attributes and yield}

Various yield attributes like early emergence (6.1 days), higher plant height $(105.3 \mathrm{~cm})$, early days to $50 \%$ flowering (78 days), more number of primary branches per plant (10.8), number of capitula per plant (22.4) and number of seeds per capitulam (28.1) were recorded in selective mechanization over farmer practice (Table 1). Proper plant to plant population and optimum management practice can be adopted under mechanization than farmer practice which helps to increase or record good growth of crop than famer practice.

From Table 1, found that case of safflower seed yield (1350 kg/ha) which was higher than farmer practice $(1087 \mathrm{~kg} / \mathrm{ha})$. Seed yield of safflower was increased by $24 \%$ observed under mechanized condition compared to farmers practice similar result recorded by Mandal (1975). Similarly Singh and Singh (1975) concluded that tractor farms gave higher yields of wheat, paddy and sugarcane and produced a higher overall gross output per hectare than non-tractor farms.

Table.1 Following parameter selected under selective mechanization vis-à-vis Farmers practice in terms of yield, economics and energy budgeting of Safflower

\begin{tabular}{|c|c|c|c|c|}
\hline $\begin{array}{l}\text { Sr. } \\
\text { no. }\end{array}$ & Name of operation & $\begin{array}{c}\text { Selective mechanized } \\
\text { plot (SMP) }\end{array}$ & Name of operation & Farmer practice (FP) \\
\hline 1. & Sowing & $\begin{array}{l}\text { With seed cum } \\
\text { fertilizer drill }\end{array}$ & Sowing & $\begin{array}{l}\text { Behind the bullock } \\
\text { drawn plough }\end{array}$ \\
\hline 2. & Inter cultivation & Power weeder & Inter cultivation & $\begin{array}{l}\text { Inter cultivation with } \\
\text { bullock drawn Danthi }\end{array}$ \\
\hline 3. & Plant protection & Power sprayers & Plant protection & Knapsack sprayer \\
\hline 4. & $\begin{array}{l}\text { Harvesting, Threshing } \\
\text { and winnowing }\end{array}$ & $\begin{array}{l}\text { Combine with minute } \\
\text { modification }\end{array}$ & $\begin{array}{l}\text { Harvesting, } \\
\text { Threshing and } \\
\text { winnowing }\end{array}$ & Manual \\
\hline
\end{tabular}




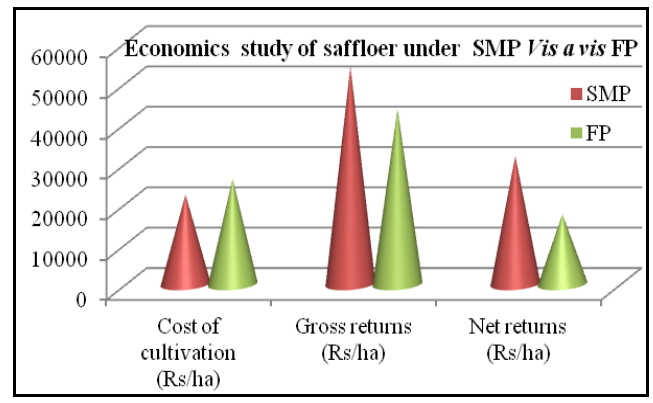

A.

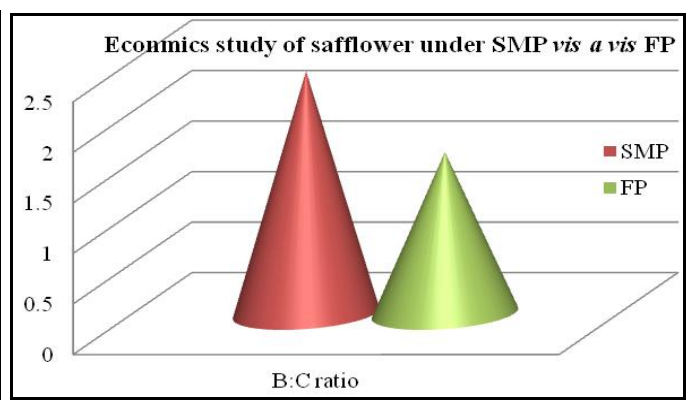

B.

*SMP-Selective mechanization plot *FP-Farmer practice

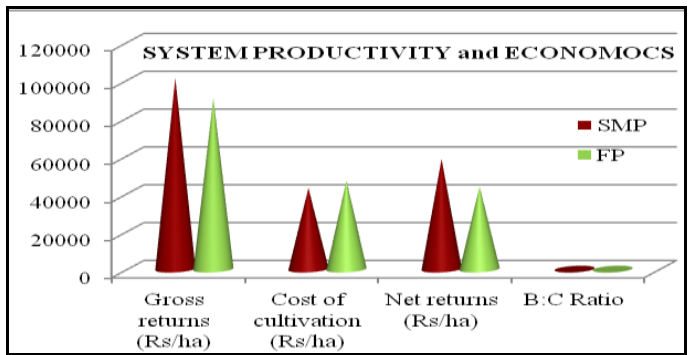

\section{Effect on economics}

From graphical (Graph-2) presentation can observed that SMP recorded higher GMR, NMR and B: C ratio over farmer practice. Slimier NCAER (1973) compared the values of annual farm output per hectare of net sown area under different levels of mechanization. The output per hectare was found to increase as the level of mechanization increased. In case of cost of cultivation under farmer practice cost of cultivation recorded higher than mechanization. Olmstead and Rhode (2001) also reach similar conclusion after studying the benefits from adoption of farm tractors.

From graph (Graph-3) can observed that SMP recorded higher GMR, NMR and $\mathrm{B}$ : $\mathrm{C}$ ratio over farmer practice under system productivity.

\section{References}

Aggarwal, B. 1983. Mechanization in Indian agriculture. An analytical study based on Punjab. Monograph in Economics No.6 Delhi School of Economics. 6-13. APO. 1983. Farm mechanization in Asia, Asian Productivity Organization, Tokyo. Pp. 18-24.

Kolsarıcı, Ö., Alluşoğlu, S. And Kaya, M.D., 2005. The Effects of Tillage and Nitrogen Doses on Water Use Efficiency, Soil Moisture and Seed Characters of Safflower (Carthamus tinctorius L.) in Wheat-Safflower Rotation System. 6th International Safflower Conference, Istanbul 6-10 June, 2005. p: 126-131.

Mandal, G.C. and Prasad R.N. 1975. Economics of Tractor Cultivation-A study of the district of Shahabad, Bihar. Shanti Niketan, Agro-Economic Research Centre, Visva Bharati.

Olmstead, Alan L., and Paul W. Rhode (2001) "Reshaping the Landscape: The Impact and Diffusion of the Tractor in American Agriculture, 1910-1960." The Journal of Economic History 61, no. 3 (2001): 663-98.

Singh, L.R. and Singh, R.V. 1975. Impact of 
Farm Mechanization on Human and Bullock Labour Use in Two Regions of U.P. Dept of Agri. Economics. G.B. Pant Univ. of Agril. and Technology. Srivastava N.S.L. (2006), 'Farm Power Sources, their Availability and Future Requirements to Sustain Agricultural
Production' in IASRI (2006). Study relating to formulating long-tem mechanization strategy for each agroclimatic zone/state in India. Indian Agricultural Statistics Research Institute, New Delhi, India.

\section{How to cite this article:}

Bhutada, P.O., S.B. Ghuge and Kote, G.M. 2020. Influence of Mechanization on SoybeanSafflower Cropping System in terms of Growth, Yield and Economics. Int.J.Curr.Microbiol.App.Sci. 9(08): 1303-1306. doi: https://doi.org/10.20546/ijcmas.2020.908.147 